\title{
Peptides Derived from Glycoproteins H and B of Herpes Simplex Virus Type 1 and Herpes Simplex Virus Type 2 Are Capable of Blocking Herpetic Infection in vitro
}

\author{
Abraham Cetina-Corona ${ }^{a}$ Uriel López-Sánchez ${ }^{a, c}$ Juana Salinas-Trujano ${ }^{a}$ \\ Alfonso Méndez-Tenorio ${ }^{b}$ Blanca Lilia Barrón ${ }^{a}$ Jesus Torres-Flores ${ }^{a}$ \\ ${ }^{a}$ Laboratorio de Virología, Departamento de Microbiología, and b Departamento de Bioquímica, Escuela Nacional \\ de Ciencias Biológicas, Instituto Politécnico Nacional, Mexico City, Mexico; ' Institut de Génétique Moléculaire de \\ Montpellier, Centre National de la Recherche Scientifique (CNRS UMR 5535), Montpellier, France
}

\section{Keywords}

Antiviral peptides $\cdot$ Herpes simplex viruses type $1 \cdot$ Herpes

simplex viruses type 2 - Glycoprotein $\mathrm{H}$ · Glycoprotein B

\begin{abstract}
Aims: The aim of this study was to design peptides derived from glycoproteins $\mathrm{H}(\mathrm{gH})$ and $\mathrm{B}(\mathrm{gB})$ of herpes simplex viruses type 1 (HSV-1) and type 2 (HSV-2) with the potential to block herpetic infection and to evaluate their ability to inhibit HSV-1 and HSV-2 infection in vitro. Methods: A library of continuous 15-25 residue stretches (CRSs) located at the surface of $\mathrm{gH}$ and $\mathrm{gB}$ from HSV-1 and HSV-2 was created. These CRSs were analyzed, and only those that were highly flexible and rich in charged residues were selected for the design of the antiviral peptides (AVPs). The toxicity of the AVPs was evaluated by MTT reduction assays. Virucidal activity of the AVPs was determined by a plaque reduction assay, and their antiviral effect was measured by cell viability assays. Results and Conclusion: Four AVPs (CB-1, CB-2, U-1, and $\mathrm{U}-2$ ) derived from $\mathrm{gB}$ and $\mathrm{gH}$ were designed and synthetized, none of which showed high levels of toxicity in Vero
\end{abstract}

\section{KARGER}

E-Mail karger@karger.com

www.karger.com/int cells. The U-1 and U-2 gB-derived AVPs showed high virucidal and antiviral activities against both HSV-1 and HSV-2. The $\mathrm{gH}$-derived peptide $\mathrm{CB}-1$ showed high virucidal and antiviral activities against HSV-2, while CB-2 showed similar results against HSV-1. The peptides CB-1 and CB-2 showed higher $\mathrm{IC}_{50}$ values than the $\mathrm{U}-1$ and $\mathrm{U}-2$ peptides.

(c) 2017 S. Karger AG, Basel

\section{Introduction}

Herpes simplex viruses type 1 (HSV-1) and type 2 (HSV-2) are widely spread all around the world, causing infections that range from ulcerations of the oral and genital mucous membranes to severe infections like herpetic encephalitis and disseminated infections in newborns [14]. One of the most striking features of herpes simplex viruses is that they can establish a latency state in sensory and autonomic ganglia, reactivating periodically due to several stimuli, which include stress and fever, amongst others [5]. Clinically, HSV-1 has been mainly associated with orofacial infections, and according to the World 
Health Organization, more than 3.7 billion people under 50 years of age are infected with this virus around the world $[6,7]$. On the other hand, HSV-2 is the principal causative agent of genital herpes, and according to the WHO, more than 417 million people between 15 and 49 years of age are infected with this virus worldwide [8-10], making HSV-2 infections one of the most common sexually transmitted diseases globally. Even more, it has been suggested that HSV-2-infected people may be more susceptible of acquiring HIV-1; therefore, herpetic infections an important public health issue nowadays [11-14].

The current treatment for herpetic infections is based on the use of nucleotide analogues that competitively inhibit the viral DNA polymerase [15]. Nevertheless, the emergence of an increased number of acyclovir-resistant HSV variants has been observed in recent years, especially in HIV-infected patients and immunosuppressed transplant recipients $[15,16]$. Thus, the development of novel antivirals designed to block other steps of the replication cycle represents an important alternative to treat patients infected with acyclovir-resistant HSV-1 or HSV-2.

To enter their host cells, herpes simplex viruses need to fuse the viral envelope either with the plasma membrane or with the membrane of the endocytic vesicles that HSV use to enter certain cell types [17]; in both cases, the membrane fusion step during HSV entry is mediated by 4 viral glycoproteins: $\mathrm{gD}, \mathrm{gB}$, and the heterodimer $\mathrm{gH}-\mathrm{gL}$ [18].

The first step in the HSV entry process is the interaction between $\mathrm{gD}$ and different molecules in the cell surface, which include the herpes virus entry mediator, nectin-1, and heparan sulfate molecules modified by $3-\mathrm{O}$ sulfotransferases [18-20]. This interaction induces a conformational change in the C-terminal domain of $\mathrm{gD}$ (profusion domain) [21] that is sufficient to trigger membrane fusion, elegantly executed by the viral glycoproteins $\mathrm{gB}$ and $\mathrm{gH}-\mathrm{gL}$. The most accepted model of HSV fusion suggests that the profusion domain in $\mathrm{gD}$ is capable of interacting with the heterodimer $\mathrm{gH}$-gL; this interaction increases the affinity of $\mathrm{gH}$-gL for $\mathrm{gB}$ priming the latter for fusion. The conformational change in $\mathrm{gB}$, induced by its interaction with $\mathrm{gH}-\mathrm{gL}$, is enough to bring the viral envelope and the cellular membrane together, resulting in the liberation of viral capsids into the cytoplasm $[22,23]$.

Due to the important role of $\mathrm{gD}, \mathrm{gB}$, and $\mathrm{gH}$-gL during the HSV entry process $[24,25]$, these glycoproteins constitute an important target for the design of new antiviral drugs, which ideally should be able to block their ability to complete membrane fusion. Previous efforts have been made to treat herpetic infections with AVPs; hydrophobic peptides derived from $\mathrm{gH}$ of HSV-1 were capable of blocking the entry of HSV-1 in vitro [26-28]. Akkarawongsa et al. [29] performed a screening of a library of overlapping peptides derived from gB of HSV-1 and found different peptides that were capable of blocking herpetic infection.

In this work, 4 antiviral peptides (AVPs) derived from different regions in $\mathrm{gB}$ and $\mathrm{gH}$ of both HSV-1 and HSV2 , with the potential of blocking the protein-protein interactions essential for membrane fusion, were designed and tested for their ability to inhibit HSV infection in vitro.

\section{Materials and Methods}

\section{Antiviral Peptide Design and Synthesis}

For the design of the AVPs, the crystal structures of HSV-2 gH (3M1C) and HSV-1 gB (2 GUM) were downloaded from the Protein Data Bank [30] and analyzed with the molecular visualization system Pymol [31] to find continuous residue stretches (CRSs) of 15-25 amino acids at the surface of each glycoprotein for further analysis. Moreover, the amino acid sequences of HSV-1 gH and HSV - 2 gB, were downloaded from the GenBank NCBI data base [32] and aligned with the amino acid sequences of the CRSs previously selected using PRALINE [33]. The highly conserved CRSs between HSV-1 and HSV-2 were further analyzed to determine their flexibility and charge using the ProtScale and EMBOSS servers $[34,35]$. Four peptides (CB-1, CB-2, U-1, and U-2), ranging from 18-20 residues, were selected from the CRSs that met the previous criteria chemically synthetized (Invitrogen ${ }^{\mathrm{TM}}$ ).

\section{Cells and Viruses}

Vero cells were grown in Medium 199 supplemented with 10\% fetal bovine serum (FBS) (Invitrogen ${ }^{\mathrm{TM}}$ ). Cells were incubated at $37^{\circ} \mathrm{C}$ in a $5 \% \mathrm{CO}_{2}$ atmosphere. Virus strains HSV-1 (MacIntyre) and HSV-2 (strain G) were both propagated in Vero cells; briefly, cells were adsorbed with a MOI of 0.001 of the virus and incubated for $30 \mathrm{~min}$ at $37^{\circ} \mathrm{C}$. After the adsorption period, the inoculum was removed and fresh maintenance media was added (M199 supplemented with $1 \%$ FBS) and the infection was left to proceed until complete cytopathic effect (CPE) was observed, the lysates were clarified and titrated by the TCID 50 method.

\section{Cytotoxicity Assay}

Four-well plates were seeded with $1.25 \times 10^{4}$ Vero cells/well and incubated for $24 \mathrm{~h}$ at $37^{\circ} \mathrm{C}$ in a $5 \% \mathrm{CO}_{2}$ atmosphere, growth medium was removed, and cells were washed twice with PBS. The peptides were diluted at different concentrations in maintenance media (M199 supplemented with 1\% FBS) and incubated with the cell monolayers for $48 \mathrm{~h}$ at $37^{\circ} \mathrm{C}$ in a $5 \% \mathrm{CO}_{2}$ atmosphere. After the incubation period, cell viability was evaluated by an MTT assay; briefly, a solution of MTT ( $1 \mathrm{mg} / \mathrm{mL}$ in PBS) was added to the cells and incubated for $5 \mathrm{~h}$ at $37^{\circ} \mathrm{C}$. Later, a solution of SDS-HCl $(10 \%$ SDS and $0.01 \mathrm{~N} \mathrm{HCl})$ was added to each well and incubated overnight (in the dark) at room temperature. After this period, the 
Table 1. Bioinformatical analysis of glycoproteins H and B from HSV-1 and HSV-2 for the design of the antiviral peptides

\begin{tabular}{|c|c|c|c|c|c|c|}
\hline \multirow[t]{3}{*}{ Glycoprotein H } & CRS-1 (173-191) & CRS-1 & CRS-3 & CRS-3 & CB-1 & QATRSETPVEVLAQQTHG \\
\hline & CRS-2 (562-585) & CRS-2 & CRS-4 & CRS-4 & $\mathrm{CB}-2$ & PEASHRCGGQSANVEPRIL \\
\hline & CRS-3 (609-626) & CRS-3 & & & & \\
\hline \multirow[t]{5}{*}{ Glycoprotein B } & CRS-1 (126-145) & CRS-1 & CRS-1 & CRS-2 & U-1 & HRDDHETDMELKPANAATRT \\
\hline & CRS-2 (224-243) & CRS-2 & CRS-2 & CRS-5 & U-2 & CIGKDARDAMDRIFARRYNA \\
\hline & CRS-3 (303-321) & CRS-3 & CRS-3 & & & \\
\hline & CRS-4 (387-405) & CRS-4 & CRS-5 & & & \\
\hline & CRS-5 (413-432) & CRS-5 & & & & \\
\hline
\end{tabular}

absorbance of each well was read at $540 \mathrm{~nm}$ using the using Epoch Microplate Spectrophotometer - BioTek. The toxicity percentage in Vero cells for each AVP dilution was calculated by using the following formula: $[(\mathrm{A}-\mathrm{B}) / \mathrm{A}] \times 100$, where $\mathrm{A}$ is the absorbance $\left(\mathrm{OD}_{540}\right)$ from the untreated cells and $\mathrm{B}$ the absorbance from the cells treated with the AVPs $[36,37]$.

\section{Virucidal Activity of the AVPs}

To assess the virucidal activity of the AVPs, $150 \mu \mathrm{L}$ of a mixture composed of 100 PFUs of either HSV-1 or HSV-2 and different concentrations of the AVPs diluted in maintenance media (M199 supplemented with $1 \%$ FBS) were prepared and then incubated for $1 \mathrm{~h}$ at $37^{\circ} \mathrm{C}$. The growth media was removed from Vero cell monolayers grown to confluence on 24 -well plates and then $150 \mu \mathrm{L}$ of the virus-peptide mixture was added to each well and incubated for $30 \mathrm{~min}$ at $37^{\circ} \mathrm{C}$ to let the virus adsorb into the cell surface. After the incubation period, the virus-peptide mixture was removed and the cell monolayers were washed twice with PBS to remove the unbound virus and the residual AVPs. Finally, an overlay (1\% agarose in M199 supplemented with 3\% FBS) was added to each well and the infection was left to proceed for 3 days or until the viral control showed more than $80 \%$ of CPE. The cells were then fixed with $80 \%$ acetone in PBS and stained with crystal violet $[38,39]$.

\section{Antiviral Activity Assay}

The antiviral activity of the AVPs was measured by means of a cell viability assay. Briefly, 4-well plates were seeded with $1.25 \times$ $10^{4}$ Vero cells/well and incubated for $24 \mathrm{~h}$ at $37^{\circ} \mathrm{C}$ in a $5 \% \mathrm{CO}_{2}$ atmosphere. After the incubation period, the growth media was removed from the cells and 100 TCID $_{50}$ of either HSV-1 or HSV-2 were adsorbed into the cell monolayers for $2 \mathrm{~h}$ at $4^{\circ} \mathrm{C}$. After the adsorption period, the inoculums were removed and the cells were washed twice with cold PBS to remove the unbound virus. Afterwards, the AVPs diluted in maintenance media (M199 supplemented with $1 \%$ FBS) were added to each well and incubated for $2 \mathrm{~h}$ at $37^{\circ} \mathrm{C}$ to allow virus entry. Then the peptide dilutions were removed and fresh maintenance media (M199 supplemented with
$1 \% \mathrm{FBS}$ ) was added to the cells, which were incubated for 3 days at $37^{\circ} \mathrm{C}$ or until more than $80 \%$ of CPE developed in the viral controls. Cell viability of each well was determined by an MTT assay as previously described. The absorbance was directly proportional to the number of living cells in culture. The percentage of protection of each peptide was calculated according to the following formula: $[(A-B) /(C-B)] \times 100$, where $A$ is the absorbance of the AVP-treated infected cells, B is the absorbance of the viral control, and $\mathrm{C}$ is the absorbance of the cell control [40].

\section{Results}

\section{Design of $A V P s$}

The regions of $\mathrm{gH}$ and $\mathrm{gB}$ that were used for the design of the AVPs were selected taking into account the following parameters: they should derive from CRSs of 15-25 amino acids found on the exposed surfaces of both glycoproteins ( $\mathrm{gH}$ and $\mathrm{gB}$ ), they should have an identical amino acid composition between HSV-1 and HSV-2, be highly flexible, and possess more than 7 charged residues in their amino acid sequence.

The search for CRSs in the crystal structures of $\mathrm{gH}$ of HSV -2 and the gB of HSV -1 revealed 5 CRSs in the exposed surfaces of $\mathrm{gH}$ and 8 on the exposed surfaces of $\mathrm{gB}$ (Table 1). To increase the possibility that the AVPs were capable of blocking the infection by both HSV-1 and HSV-2, only those CRSs that showed high amino acid conservation between $\mathrm{gH}$ and $\mathrm{gB}$ of both viruses were selected for further analysis. Surprisingly, all the CRSs that were initially selected met this criterion, so none of them was discarded. 


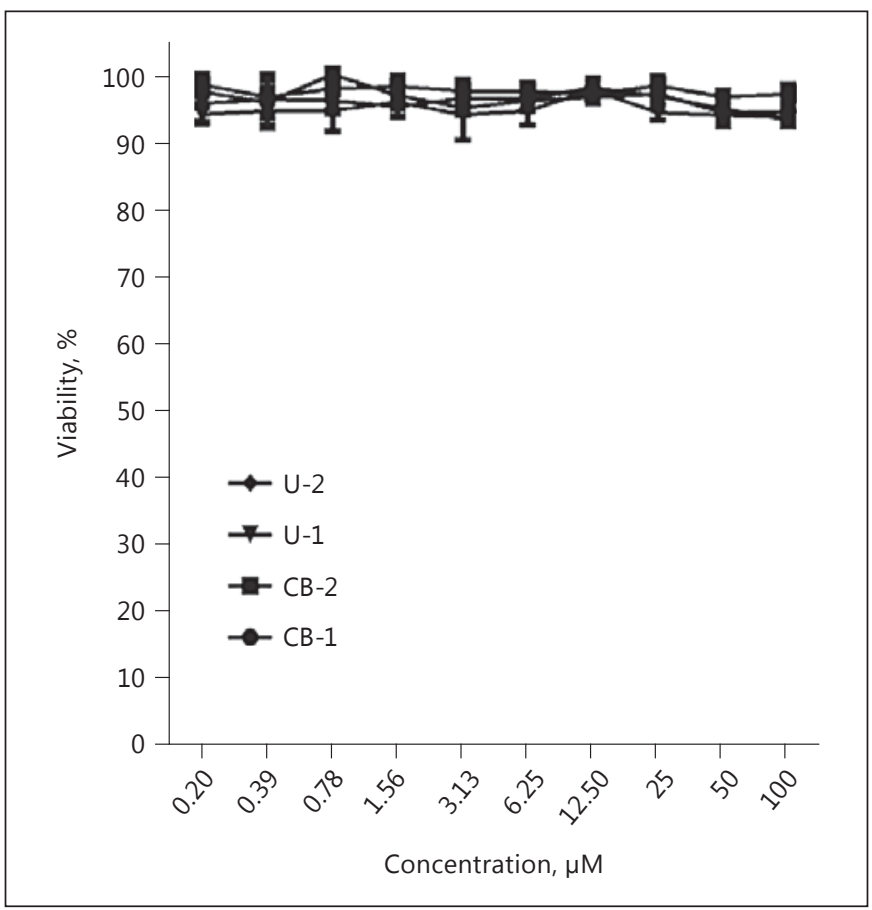

Fig. 1. Toxicity of the AVPs in Vero cells. Confluent monolayers of Vero cells grown in 96-well plates were incubated with $100 \mu \mathrm{M}$ of each AVP for $24 \mathrm{~h}$ at $37^{\circ} \mathrm{C}$. After the incubation period, cell viability was measured by an MTT assay as described in Materials and Methods. Data are expressed as percent of viability and were normalized against the viability of nontreated Vero cell monolayers. The arithmetic means and standard deviations of 3 independent experiments performed in duplicate are shown.
Flexible regions and charged residues are more likely to be involved in protein-protein interactions, so the next parameters considered to select the CRSs that were used for the design of the AVPs were their flexibility and their number of charged residues. Only 2 CRSs for gH and 3 for $\mathrm{gB}$ were found to be highly flexible (Table 1). Finally, when the number of charged residues of the CRSs was considered (more than 7 charged amino acid residues), only 2 CRSs for $\mathrm{gH}$ and 2 for $\mathrm{gB}$ (Table 1) were selected and used for the design of the AVPs (final sequences listed in Table 1).

\section{Cytotoxicity of the AVPs}

The cytotoxicity of the 4 AVPs previously designed, 2 derived from $\mathrm{gH}$ (CB-1 and $\mathrm{CB}-2)$ and 2 derived from $\mathrm{gB}$ (U-1 and U-2), were evaluated in Vero cells (Fig. 1). None of the peptides had a significant effect over cell viability at any of the concentrations tested $(0-100 \mu \mathrm{M})$.

\section{Virucidal Activity of the Antiviral Peptides}

The antiviral peptides derived from $\mathrm{gB}$ (U-1 and $\mathrm{U}-2$ ) can reduce the infectivity of both HSV-1 and HSV-2 when they were preincubated with the viral particles, showing a reduction of more than $80 \%$ with a concentration of $100 \mu \mathrm{M}$ of each peptide (Fig. 2a, b). However, both peptides derived from $\mathrm{gH}$ (CB-1 and CB-2) have a differential activity against HSV-1 and HSV-2 (Fig. 2c, d). The virucidal activity of the peptide CB-1 is relatively low
Fig. 2. Virucidal activity of gB- and gH-derived AVPs. Approximately 100 PFUs of either HSV-1 or HSV-2 were incubated with various concentrations of AVPs diluted in maintenance media and incubated for $1 \mathrm{~h}$ at $37^{\circ} \mathrm{C}$. The peptide-treated virus was added to confluent Vero cell monolayers grown on 24-well plates and allowed to adsorb for $30 \mathrm{~min}$ at $37^{\circ} \mathrm{C}$. The excess virus was removed and the cells were washed twice with PBS to remove unbound virus. An overlay was added and the infection was left to proceed for $72 \mathrm{~h}$ or until the viral control showed CPE. Data are expressed as percentage of viral infectivity and normalized against the infectivity of the virus treated with a random peptide. The arithmetic means and standard deviations of 3 independent experiments performed in duplicate are shown. a U-1. b U-2. c CB-1. d CB-2.
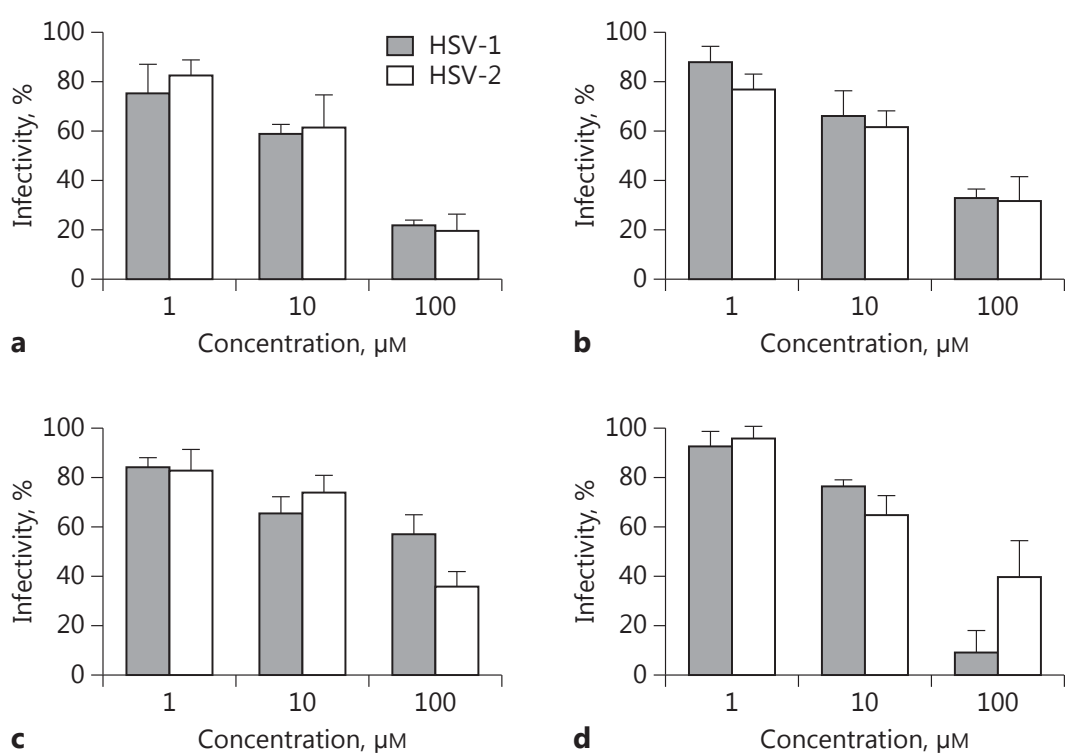
against both viruses (not more than 50\%) at the highest concentration tested $(100 \mu \mathrm{M})$. Nevertheless, the virucidal activity of the CB-2 peptide is greater for HSV-1, causing a reduction on the infectivity of this virus of more than $90 \%$, but its activity is limited against HSV -2 .

\section{Antiviral Activity of $g B$-Derived AVPs}

Both AVPs derived from gB (U-1 and U-2) showed antiviral activity against HSV-1 and HSV-2, but the U-1 peptide was more effective against both viruses, achieving more than $80 \%$ protection at a concentration $6.25 \mu \mathrm{M}$. In

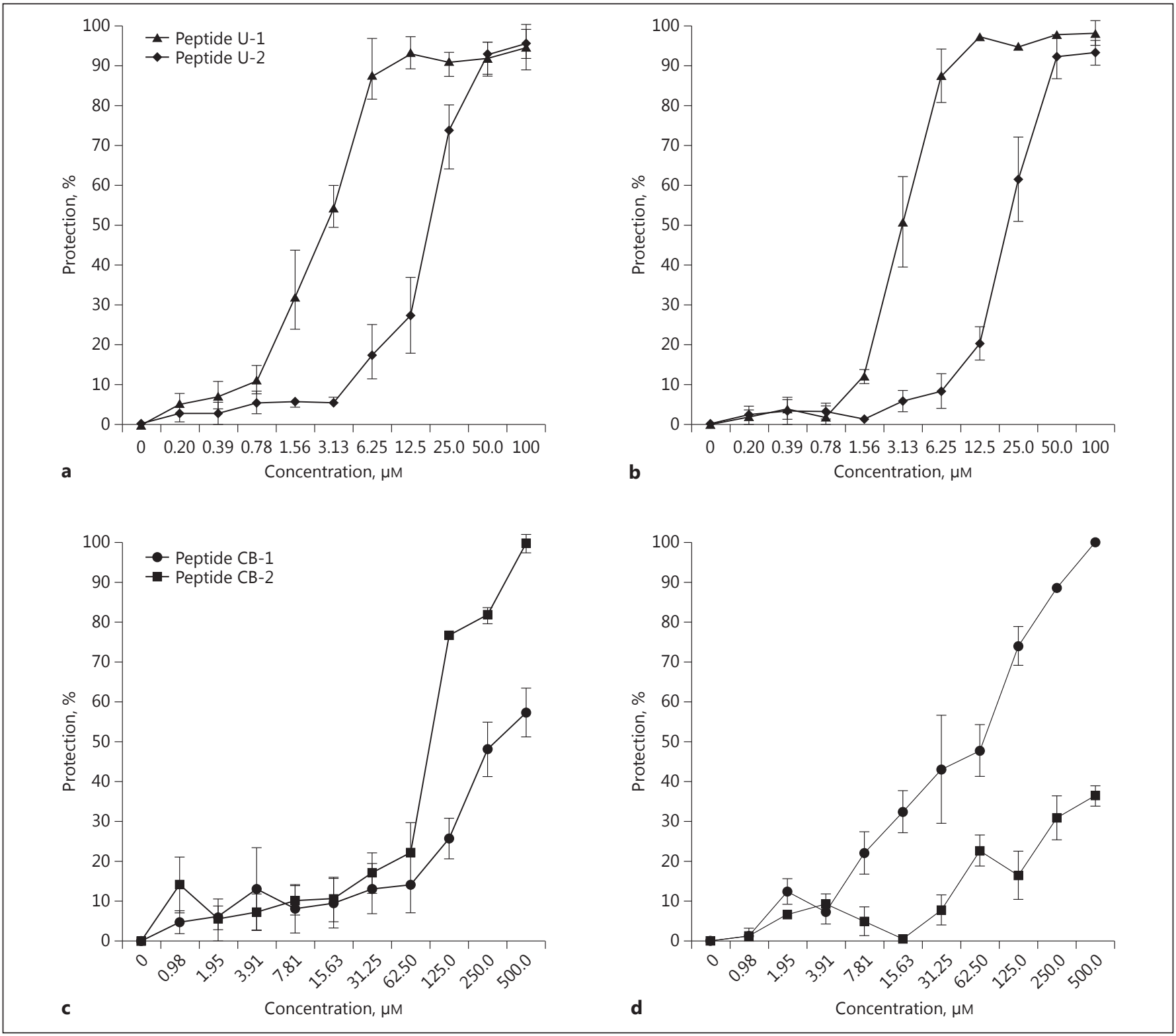

Fig. 3. Antiviral activity of gB- and gH-derived AVPs. Approximately 100 TCID $_{50}$ of either HSV-1 or HSV-2 were added to confluent Vero cell monolayers grown on 96-well plates and allowed to adsorb for $2 \mathrm{~h}$ at $4^{\circ} \mathrm{C}$. After the adsorption period, the inoculums were removed and the cells were washed twice with cold PBS to remove the unbound virus. The diluted AVPs were added to each well and incubated for $2 \mathrm{~h}$ at $37^{\circ} \mathrm{C}$ to allow virus entry. The viruspeptide mixture was removed and the infection was left to proceed for $72 \mathrm{~h}$. a Antiviral activity of the gB-derived peptides against HSV-1. b Antiviral activity of the gB-derived peptides against $\mathrm{HSV}-2$. c Antiviral activity of the gH-derived peptides against HSV-1. d Antiviral activity of the gH-derived peptides against HSV-2. Data are expressed as percent of protection, calculated as described in Materials and Methods. The arithmetic means and standard deviations of 3 independent experiments performed in duplicate are shown. 
contrast, the U-2 peptide seemed to be less effective against both viruses showing the same amount of protection at a higher concentration $(50 \mu \mathrm{M})$ (Fig. 3a, b). Our results also suggest that the antiviral effect of both of the gB-derived peptides may be taking place at a postbinding step since the viral particles were preadsorbed into the cells before the addition of the peptides.

\section{Antiviral Activity of $g H$-Derived AVPs}

The AVPs derived from $\mathrm{gH}$ (CB-1 and CB-2) showed a differential antiviral activity against HSV -1 and HSV -2 . The CB-1 peptide achieved less than $60 \%$ protection against HSV-1 at the highest concentration tested (500 $\mu \mathrm{M})$; in contrast, the same peptide induced more than $90 \%$ protection against HSV-2 at a concentration of 250 $\mu \mathrm{M}$ (Fig. 3c, d). On the other side, CB-2 showed more than 90\% protection against HSV-1 (Fig. 3c) at the highest concentration tested $(500 \mu \mathrm{M})$, but less than $40 \%$ of protection at the same concentration for HSV-2.

In comparison to the $\mathrm{gB}$-derived peptides, the gH-derived peptides are less efficient in blocking the infection by HSV-1 and HSV-2. Moreover, none of the gH-derived peptides was capable of blocking the infection by both viruses. Furthermore, higher concentrations of the $\mathrm{gH}$ derived peptides, CB-1 and CB-2, are required to produce the same amount of protection observed for the gB-derived peptides, U-1 and U-2 (Fig. 3).

\section{Discussion}

Enveloped viruses need to fuse their viral envelope either with the plasmatic membrane or with endosomal membranes in order to successfully deliver the viral capsid into the cell cytoplasm, a crucial event for several viruses that allows the beginning of their replication cycle [41]. For herpes simplex viruses, the viral entry process takes place with the aid of 4 viral glycoproteins: $g D, g B$, $\mathrm{gH}$, and $\mathrm{gL}$, all of which have been proven to be essential for these viruses to carry out membrane fusion [42].

The initial step during HSV entry is the interaction between $\mathrm{gD}$ and one of the several cellular receptors that have been described to date, which include the herpes virus entry mediator and several members of the nectin superfamily [43], amongst others. This interaction triggers a conformational change in $\mathrm{gD}$, which has been proposed to be important for the activation of the gH-gL complex [44]. Once activated, this complex could then activate gB, which is considered to be the executor of membrane fusion [45, 46]. Due to their importance for HSV entry, the protein- protein interactions that take place between the different viral glycoproteins that execute membrane fusion are a good target for the design of novel antivirals that could specifically block these interactions to block virus entry.

The design of the antiviral peptides took into account several criteria that have been observed to be important for protein-protein interactions. In the first place, a search for exposed CRSs between 15 and 25 amino acids was carried out, taking into account that the exposed surfaces of proteins are most likely to be involved in protein-protein interactions and that for other viruses, like Dengue and influenza A viruses, neutralizing antibodies have been shown to bind exposed surfaces of the viral glycoproteins that are essential for viral entry $[47,48]$.

To refine the AVP selection, the amino acid conservation of these CRSs between HSV-1 and HSV-2 was taken into account. Interestingly, these CRSs had high amino acid conservation in the $\mathrm{gH}$ and $\mathrm{gB}$ of both viruses, suggesting that they might be involved in a common process for both viruses. Flexibility was the third criteria taken into account for the design of the AVPs since flexible regions of proteins are usually involved in protein-protein interactions [49]. Finally, only those CRSs with more than 7 charged residues were selected since electrostatic interactions play a major role in protein-protein interfaces [50].

Two antiviral peptides derived from each glycoprotein were selected. Interestingly, the 2 peptides derived from $\mathrm{gB}$ showed the highest efficiency to inhibit the infection by HSV-1 and HSV-2, in both virucidal assays and antiviral activity assays. We hypothesize that the gB-derived peptides might interact with upstream components of the entry cascade. Since the interactions between $\mathrm{gH}-\mathrm{gL}$ are necessary to trigger $\mathrm{gB}$ for membrane fusion, these peptides might be acting as competitive inhibitors, preventing the activation of $\mathrm{gB}[46]$.

Surprisingly, the gH-derived peptides showed a differential activity against HSV-1 and HSV-2, even though the sequence homology between the $\mathrm{gH}$ of both viruses was considered in the design. We believe that these peptides may be interacting with glycoprotein $\mathrm{D}$, which is the least conserved protein between both viruses (85\%) and is responsible for the activation of the heterodimer gH-gL [42, 51].

The virucidal activity shown by the AVPs suggests that there might be a direct interaction between the peptides and the viral particles, but whether the peptides can interact with the viral envelope proteins and which proteins might be affected by this interaction still needs to be determined. We also demonstrated that the AVPs could still affect the infection process once the virus has been ad- 
sorbed in the viral membrane, which suggests that the antiviral activity of the peptides occurs at a postbinding step. The exact moment during the viral entry cascade that is affected by the peptides or if the peptides affect postentry events is now being elucidated.

Here we demonstrate that HSV glycoproteins involved in the entry process might be a good target for the design of antiviral molecules, specifically small peptides that could act as competitive inhibitors to prevent herpetic infections. We are currently working to reduce the effective concentrations of the peptides proposed in this study, either by chemical modification or by their attachment to different types of dendrimers.

\section{Acknowledgements}

The present work was supported by SIP-IPN 20150989 and 20161619.

\section{Disclosure Statement}

None of the authors of this paper has a financial or personal relationship with other people or organizations that could inappropriately influence or bias the content of the paper.

\section{References}

1 Cook ML, Bastone VB, Stevens JG: Evidence that neurons harbor latent herpes simplex virus. Infect Immun 1975;9:946-951.

2 Kimberlin DW: Herpes simplex virus infections in neonates and early childhood. Semin Pediatr Infect Dis 2005;16:271-281.

3 Chayavichitsilp P, Buckwalter JV, Krakowski AC, Friedlander SF: Herpes simplex. Pediatr Rev 2009;30:119-129.

4 Curtis N, Finn A, Pollard AJ, Thompson C, Whitley R: Neonatal herpes simplex virus infections: where are we now?; in: Hot Topics in Infection and Immunity in Children VII. New York, Springer, 2011, vol 697, pp 221-230.

5 Lee S, Ives AM, Bertke AS: Herpes simplex virus 1 reactivates from autonomic ciliary ganglia independently from sensory trigeminal ganglia to cause recurrent ocular disease. J Virol 2015;89:8383-8391.

6 Nahmias AJ, Lee FK, Beckman-Nahmias S: Sero-epidemiological and -sociological patterns of herpes simplex virus infection in the world. Scand J Infect Dis Suppl 1990;69:1936.

7 Looker KJ, Magaret AS, May MT, Turner KM, Vickerman P, Gottlieb SL, Newman LM: Global and regional estimates of prevalent and incident herpes simplex virus type 1 infections in 2012. PLoS One 2015; 10:e0140765.

8 Halioua B, Malkin JE: Epidemiology of genital herpes - recent advances. Eur J Dermatol 1999;9:177-184.

9 Pereira VSS, Moizeis RNC, Fernandes TAAM, Araújo JMG, Meissner RV, Fernandes JV: Herpes simplex virus type 1 is the main cause of genital herpes in women of $\mathrm{Na}$ tal, Brazil. Eur J Obstet Gynecol Reprod Biol 2012;161:190-193.

10 Looker KJ, Magaret AS, Turner KM, Vickerman P, Gottlieb SL, Newman LM: Global estimates of prevalent and incident herpes simplex virus type 2 infections in 2012. PLoS One 2015;10:e114989.
11 Corey L, Wald A, Celum CL, Quinn TC: The effects of herpes simplex virus-2 on HIV-1 acquisition and transmission: a review of two overlapping epidemics. J Acquir Immune Defic Syndr 2004;35:435-445.

12 Wald A, Link K: Risk of human immunodeficiency virus infection in herpes simplex virus type 2-seropositive persons: a meta-analysis. J Infect Dis 2002;185:45-52.

13 Feng Z, Qiu Z, Sang Z, Lorenzo C, Glasser J: Modeling the synergy between HSV-2 and HIV and potential impact of HSV-2 therapy. Math Biosci 2013;245:171-187.

14 Todd J, Riedner G, Maboko L, Hoelscher M, Weiss HA, Lyamuya E, Mabey D, Rusizoka M, Belec L, Hayes R: Effect of genital herpes on cervicovaginal HIV shedding in women co-infected with HIV and HSV-2 in Tanzania. PLoS One 2013;8:e59037.

15 Griffiths PD: A perspective on antiviral resistance. J Clin Virol 2009;46:3-8.

16 Arellano-Galindo J, Barron BL, del Carmen Herrera-Martinez E, Santos-Esteban E, Reyes-Teran G, Velazquez-Guadarrama N, Vargas-Infante Y: Point Mutations and Antiviral Drug Resistance. Rijeka, INTECH Open Access Publisher, 2012.

17 Milne RSB, Nicola AV, Whitbeck JC, Eisenberg RJ, Cohen GH: Glycoprotein D receptordependent, low-pH-independent endocytic entry of herpes simplex virus type 1. J Virol 2005;79:6655-6663.

18 Carfí A, Willis SH, Whitbeck JC, Krummenacher C, Cohen GH, Eisenberg RJ, Wiley DC: Herpes simplex virus glycoprotein $\mathrm{D}$ bound to the human receptor HveA. Mol Cell 2001; 8:169-179.

19 Giovine P, Settembre EC, Bhargava AK, Luftig MA, Lou H, Cohen GH, Eisenberg RJ, Krummenacher C, Carfi A: Structure of herpes simplex virus glycoprotein $\mathrm{D}$ bound to the human receptor nectin-1. PLoS Pathog 2011; $7: e 1002277$
20 Shukla D, Liu J, Blaiklock P, Shworak NW, Bai $\mathrm{X}$, Esko JD, Cohen GH, Eisenberg RJ, Rosenberg RD, Spear PG: A novel role for 3-O-sulfated heparan sulfate in herpes simplex virus 1 entry. Cell 1999;99:13-22.

21 Cocchi F, Fusco D, Menotti L, Gianni T, Eisenberg RJ, Cohen GH, Campadelli-Fiume G: The soluble ectodomain of herpes simplex virus $\mathrm{gD}$ contains a membrane-proximal profusion domain and suffices to mediate virus entry. Proc Natl Acad Sci USA 2004;101: 7445-7450.

22 Atanasiu D, Cairns TM, Whitbeck JC, Saw WT, Rao S, Eisenberg RJ, Cohen GH: Regulation of herpes simplex virus $\mathrm{gB}$-induced cellcell fusion by mutant forms of $\mathrm{gH} / \mathrm{gL}$ in the absence of $\mathrm{gD}$ and cellular receptors. MBio 2013;4:e00046-13.

23 Subramanian RP, Geraghty RJ: Herpes simplex virus type 1 mediates fusion through a hemifusion intermediate by sequential activity of glycoproteins D, H, L, and B. Proc Natl Acad Sci USA 2007;104:2903-2908.

24 Galdiero S, Vitiello M, D’Isanto M, Falanga A, Collins C, Raieta K, Pedone C, Browne H, Galdiero M: Analysis of synthetic peptides from heptad-repeat domains of herpes simplex virus type 1 glycoproteins $\mathrm{H}$ and B. J Gen Virol 2006;87:1085-1097.

25 Gianni T, Piccoli A, Bertucci C, CampadelliFiume G: Heptad repeat 2 in herpes simplex virus $1 \mathrm{gH}$ interacts with heptad repeat 1 and is critical for virus entry and fusion. J Virol 2006;80:2216-2224.

26 Falanga A, Vitiello MT, Cantisani M, Tarallo R, Guarnieri D, Mignogna E, Netti P, Pedone C, Galdiero M, Galdiero S: A peptide derived from herpes simplex virus type 1 glycoprotein $\mathrm{H}$ : membrane translocation and applications to the delivery of quantum dots. Nanomedicine 2011;7:925-934. 
27 Galdiero S, Falanga A, Tarallo R, Russo L, Galdiero E, Cantisani M, Morelli G, Galdiero M: Peptide inhibitors against herpes simplex virus infections. J Pept Sci 2013;19:148-158.

28 Galdiero S, Falanga A, Vitiello M, D'Isanto M, Cantisani M, Kampanaraki A, Benedetti E, Browne H, Galdiero M: Peptides containing membrane-interacting motifs inhibit herpes simplex virus type 1 infectivity. Peptides 2008; 29:1461-1471.

29 Akkarawongsa R, Pocaro NE, Case G, Kolb AW, Brandt CR: Multiple peptides homologous to herpes simplex virus type 1 glycoprotein B inhibit viral infection. Antimicrob Agents Chemother 2009;53:987-996.

30 Berman HM, Westbrook J, Feng Z, Gilliland G, Bhat TN, Weissig H, Shindyalov IN, Bourne PE: The Protein Data Bank. Nucleic Acids Res 2000;28:235-242.

31 The PyMOL Molecular Graphics System, Version 1.8. Schrödinger, LLC

32 O'Leary NA, Wright MW, Brister JR, Ciufo S, Haddad D, McVeigh R, Rajput B, Robbertse B, Smith-White B, Ako-Adjei D, Astashyn A, Badretdin A, Bao Y, Blinkova O, Brover V, Chetvernin V, Choi J, Cox E, Ermolaeva O, Farrell CM, Goldfarb T, Gupta T, Haft D, Hatcher E, Hlavina W, Joardar VS, Kodali VK, Li W, Maglott D, Masterson P, McGarvey KM, Murphy MR, O’Neill K, Pujar S, Rangwala SH, Rausch D, Riddick LD, Schoch C, Shkeda A, Storz SS, Sun H, Thibaud-Nissen F, Tolstoy I, Tully RE, Vatsan AR, Wallin C, Webb D, Wu W, Landrum MJ, Kimchi A, Tatusova T, DiCuccio M, Kitts P, Murphy TD, Pruitt KD: Reference sequence (RefSeq) database at NCBI: current status, taxonomic expansion, and functional annotation. Nucleic Acids Res 2016;44:D733-D745.

33 Simossis VA, Kleinjung J, Heringa J: Homology-extended sequence alignment. Nucleic Acids Res 2005;33:816-824.
34 Gasteiger E, Gattiker A, Hoogland C, Ivanyi I, Appel RD, Bairoch A: ExPASy: the proteomics server for in-depth protein knowledge and analysis. Nucleic Acids Res 2003;31: 3784-3788.

35 Rice P, Longden I, Bleasby A: EMBOSS: the European Molecular Biology Open Software Suite. Trends Genet 2000;16:276-277.

36 Betancur-Galvis LA, Morales GE, Forero JE, Roldan J: Cytotoxic and antiviral activities of Colombian medicinal plant extracts of the Euphorbia genus. Mem Inst Oswaldo Cruz 2002;97:541-546.

37 Pannecouque C, Daelemans D, De Clercq E: Tetrazolium-based colorimetric assay for the detection of HIV replication inhibitors: revisited 20 years later. Nat Protoc 2008;3:427434.

38 Shogan B, Kruse L, Mulamba GB, Hu A, Coen DM: Virucidal activity of a GT-rich oligonucleotide against herpes simplex virus mediated by glycoprotein B. J Virol 2006;80:47404747. Erratum in: J Virol 2011;85:1909.

39 Luganini A, Nicoletto SF, Pizzuto L, Pirri G, Giuliani A, Landolfo S, Gribaudo G: Inhibition of herpes simplex virus type 1 and type 2 infections by peptide-derivatized dendrimers. Antimicrob Agents Chemother 2011;55: 3231-3239.

40 Mahy BWJ, Kangro HO: Virology Methods Manual. Cambridge, Academic Press, 1996.

41 Lorizate M, Kräusslich HG: Role of lipids in virus replication. Cold Spring Harb Perspect Biol 2011;3:a004820.

42 Rogalin HB, Heldwein EE: Characterization of vesicular stomatitis virus pseudotypes bearing essential entry glycoproteins $\mathrm{gB}, \mathrm{gD}$, $\mathrm{gH}$, and $\mathrm{gL}$ of herpes simplex virus 1 . J Virol 2016;90:10321-10328.
43 Okubo Y, Uchida H, Wakata A, Suzuki T, Shibata T, Ikeda H, Yamaguchi M, Cohen JB, Glorioso JC, Tagaya M, Hamada H, Tahara H: Syncytial mutations do not impair the specificity of entry and spread of a glycoprotein d receptor-retargeted herpes simplex virus. J Virol 2016;90:11096-11105.

44 Fan Q, Longnecker R, Connolly SA: A Functional interaction between herpes simplex virus 1 glycoprotein $\mathrm{gH} / \mathrm{gL}$ domains I and II and $\mathrm{gD}$ is defined by using alphaherpesvirus gH and gL chimeras. J Virol 2015;89:71597169.

45 Eisenberg RJ, Atanasiu D, Cairns TM, Gallagher JR, Krummenacher C, Cohen GH: Herpes virus fusion and entry: a story with many characters. Viruses 2012;4:800-832.

46 Cooper RS, Heldwein EE: Herpesvirus gB: a finely tuned fusion machine. Viruses 2015;7: 6552-6569.

47 Lok SM, Kostyuchenko V, Nybakken GE, Holdaway HA, Battisti AJ, Sukupolvi-Petty S, Sedlak D, Fremont DH, Chipman PR, Roehrig JT, Diamond MS, Kuhn RJ, Rossmann MG: Binding of a neutralizing antibody to dengue virus alters the arrangement of surface glycoproteins. Nat Struct Mol Biol 2008; 15:321-317.

48 Ekiert DC, Bhabha G, Elsliger MA, Friesen $\mathrm{RH}$, Jongeneelen $\mathrm{M}$, Throsby M, Goudsmit J, Wilson IA: Antibody recognition of a highly conserved influenza virus epitope. Science 2009;324:246-251.

49 Teague SJ: Implications of protein flexibility for drug discovery. Nat Rev Drug Discov 2003;2:527-541.

50 Sinha N, Smith-Gill SJ: Electrostatics in protein binding and function. Curr Protein Pept Sci 2002;3:601-614.

51 Eisenberg RJ, Ponce de Leon M, Cohen GH: Comparative structural analysis of glycoprotein $\mathrm{gD}$ of herpes simplex virus types 1 and 2 . J Virol 1980;35:428-435 